\title{
PEMBERHENTIAN BUPATI GARUT DALAM PERSPEKTIF FIKIH SIYĀSAH AL-MAWARDI
}

\author{
M. Nurul Irfan \\ Universitas Islam Negeri Syarif Hidayatullah Jakarta \\ e-mail: mnurulirfan@yahoo.com
}

\begin{abstract}
This article intends to analyze the case of Garut Regent dismissal, Aceng Fikri from his position according to al-Mawardi's Fiqh Siyāsah perspective. Reasons for the dismissal was a violation of Article $28 \mathrm{f}$ of Law No. 32 / 2004 on Regional Government. The article states that the head of regional and the deputy of head of regional are prohibited from misusing authority and violation of the oath of position. In addition, he is also considered not to meet the obligation for local office as mentioned in Article 27 point (1), letter e, which is the regional head and deputy regional head have the obligation to obey and enforce all laws and regulations. In the perspective of Fiqh Siyasah of al-Mawardi, an unfairly leader can dismissed from his position. One indicator of an injustice leader is a ethical violation.
\end{abstract}

[]

Artikel ini bermaksud menganalisis kasus pemberhentian Bupati Garut, Aceng Fikri dari jabatannya dalam perspektif Fikih Siyāsah al-Mawardi. Alasan pemberhentian adalah pelanggaran terhadap Pasal 28 huruf f UU No. 32 Tahun 2004 tentang Pemerintah Daerah. Pasal tersebut menyatakan bahwa kepala daerah dan wakil kepala daerah dilarang menyalahgunakan wewenang dan melanggar sumpah atau janji jabatannya. Di samping itu, ia juga dinilai tidak dapat memenuhi kewajiban sebagai kepala daerah sebagaimana disebutkan dalam Pasal 27 angka (1) huruf e, yaitu kepala daerah dan wakil kepala daerah mempunyai kewajiban menaati dan menegakkan seluruh peraturan perundang-undangan. Dalam perspektif Fikih Siyasah al-Mawardi, seorang pemimpin yang tidak adil dapat diberhentikan dari jabatannya. Salah satu indikator ketidakadilan seorang pemimpin adalah pelanggaran terhadap etika.

Keywords: siyāsah, kepala daerah, sumpah jabatan, adil

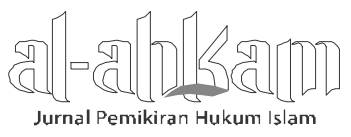




\section{Pendahuluan}

Bupati Garut Aceng Fikri bisa jadi bukan satu-satunya kepala daerah yang seharusnya diberhentikan dengan alasan serupa. Informasi pelbagai media menunjukkan bahwa pada umumnya kepala daerah baik seorang gubernur, bupati atau wali kota di berbagai daerah diberhentikan akibat tersandung kasus korupsi, yaitu pelanggaran terhadap Pasal 28 huruf d UU No. 32 Tahun 2004 yang menyatakan bahwa kepala daerah dan wakil kepala daerah dilarang melakukan korupsi, kolusi, nepotisme, dan menerima uang, barang dan/atau jasa dari pihak lain yang mempengaruhi keputusan atau tindakan yang akan dilakukannya. ${ }^{1}$

Dalam tulisan berjudul "Pemberhentian Bupati Garut Aceng Fikri dalam Perspektif Fikih Siyāsah al-Mawardi” ini terdapat tiga masalah pokok yang akan penulis cari jawabannya. Pertama, bagaimana proses dan mekanisme pemberhentian Bupati Garut Aceng Fikri menurut pemikiran fikih al-Mawardi? Kedua, apakah konsep pemikiran fikih siyāsah al-Mawardi bisa diimplementasikan dalam kehidupan berpolitik di Indonesia? Ketiga, bagaimana relevansi pemikiran fikih Siyāsah al-Mawardi dengan mekanisme pemberhentian seorang kepala daerah di Indonesia?

\section{Kewajiban Mengangkat Pemimpin Menurut al-Mawardi}

Menurut al-Mawardi, imāmah atau kepemimpinan menduduki fungsi kenabian dalam menjaga dan menegakkan ajaran agama dan dalam menjalankan roda kehidupan politik di dunia ini. ${ }^{2}$ Dalam hal kewajiban mengangkat pemimpin ulama sepakat, tetapi apakah kewajiban ini atas dasar hukum syara' atau atas dasar pertimbangan akal semata-mata? Hal ini masih diperdebatkan oleh ulama. Ada sekelompok ulama yang berpendapat bahwa mengangkat pemimpin merupakan kewajiban atas dasar akal semata, bukan berdasarkan hukum syara'. Secara logika dan kecenderungan tabiat manusia menghendaki adanya jaminan rasa aman dari berbagai ancaman dan kezaliman, dengan adanya seorang pemimpin, akan bisa menyelesaikan berbagai kasus perselisihan dan keributan antar warga, bisa dibayangkan jika tidak ada seorang pemimpin, dalam suasana seperti itu akan h. 25 .

1Undang-Undang Republik Indonesia No. 32 dan 33 Tahun 2004 (Bandung: Citra Umbara, 2013),

2al-Mawardi, al-Aḥkām al-Sulțāniyyah (Beirut: Dār al-Fikr, t.th.), h. 5.

94 Volume 24, Nomor 1, April 2014

Jurnal Pemikiran Hukum Islam 
semakin kacau. Oleh sebab itu, keberadaan seorang pemimpin sangat diperlukan atas dasar pertimbangan akal semata. ${ }^{3}$

Sementara ulama dari kelompok lain berpendapat bahwa kewajiban mengangkat pemimpin ini berdasarkan atas hukum syara' atau hukum agama, bukan berdasarkan akal semata-mata. Alasan mereka bahwa seorang pemimpin dapat dan berhak mengatur masalah-masalah syariat dan ada hubungannya dengan persoalan perbadatan. Padahal masalah ibadah tidak bisa ditentukan bedasarkan akal semata. Jangkauan akal manusia hanya terbatas pada ranah kehidupan dunia agar bisa terhindar dari berbagai kezaliman dan ketidakadilan, sedangkan masalah relasi antara hamba dengan Tuhan-nya ditentukan oleh hukum agama.

Al-Qur'an surat al-Nisā' ayat 59, Allah memerintahkan agar manusia taat kepada uli al-amr, yaitu para pemimpin yang diangkat dan memiliki kewenangan untuk melaksanakan berbagai aturan kepada seluruh rakyat yang dipimpinnya. Terkait firman Allah ini terdapat sejumlah Hadis yang menguatkan kewajiban mengangkat pemimpin dan menaatinya, antara lain Hadis yang diriwayatkan oleh Hisham ibn Urwah dari Abi Saleh, dari Abu Hurairah, sesungguhnya Rasulullah SAW bersabda: "akan memimpin kalian sepeninggalku kelak beberapa pemimpin, jika yang memimpin kalian adalah orang baik, maka ia akan memimpin dengan kebaikannya, dan jika yang memimpin kalian adalah orang jahat, ia akan memimpin dengan kejahatannya, maka dengarkan dan taatilah semua hal yang sesuai dengan nilai kebenaran, jika meraka baik maka kebaikan itu akan kalian rasakan dan juga akan mereka rasakan, tetapi jika mereka berbuat jahat, maka kalian masih bisa beruntung sedangkan mereka akan menerima akibat kejahatannya itu."4

Dengan demikian, berdasarkan ayat dan Hadis di atas, bisa diketahui bahwa hukum mengangkat pemimpin dan mentaatinya adalah wajib. Dalam hal ini, alMawardi menegaskan bahwa hukum wajib ini masuk ke dalam kategori wajib atau farḍu kifāyah sebegaimana jihad dan mencari ilmu. Jika sudah ada pemimpin yang ditaati, maka secara keseluruhan rakyat tidak berdosa lagi. Akan tetapi jika tidak ada yang mengangkat pemimpin dalam sebuah wilayah, maka segera diangkat sebagai pemimpin.

\footnotetext{
3 Ibid.

${ }^{4} \mathrm{HR}$ al-Dāruquṭni, dalam al-Dāruquṭni, Sunan al-Dāruquṭni, jilid 2 (Seri al-Maktabah al-Shāmilah), h. 55 .
}

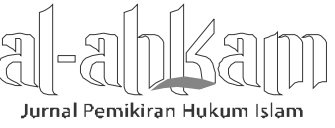


Terkait pengangkatan pemimpin, imam atau kepala negara atau kepala daerah ini, ada dua macam cara yang bisa ditempuh. Pertama, melalui mekanisme perwakilan oleh anggota atau wakil rakyat. Kedua, melalui aklamasi oleh beberapa tokoh yang sepakat untuk mengangkat salah seorang di antara para tokoh yang ada itu untuk menjadi pemimpin. Tentu saja, baik pihak yang memilih maupun pihak yang dipilih harus benar-benar memenuhi syarat yang telah ditentukan.

Adapun terkait para anggota sebagai wakil rakyat yang memilih pemimpin, beberapa syarat yang harus dipenuhi oleh mereka ada tiga hal. Pertama, mereka harus memiliki sifat adil dengan berbagai derivasi dan kriterianya. Kedua, mereka betul-betul mengenal dan memahami calon pemimpin yang akan mereka pilih dengan berbagai persyaratan pokok yang dibutuhkan. Ketiga, para wakil rakyat yang bertugas mengangkat pemimpin ini harus memiliki kepandaian, kecerdasan dan kebijaksanaan untuk untuk memilih calon pemimpin yang akan bertugas membina umat dan masyarakat dan berasal dari masyarakat setempat yang lebih menjiwai dan memahami situasi dan kondisi negara tersebut, sebab pada umumnya pemimpin yang baik adalah yang lahir dan berasal dari wilayah tersebut. ${ }^{5}$

\section{Bupati Garut Aceng Fikri dan Sumpah Jabatan}

Dari beberapa pernyataan dan tindakan sang Bupati Garut yang sudah telanjur diketahui masyarakat luas melalui pelbagai media, setidaknya terdapat beberapa hal yang bisa dikemukakan dan dicermati untuk disampaikan kritik membangun dari perspektif hukum Islam dan perundang-undangan. Beberapa hal pokok yang dapat dikemukakan itu adalah: pertama, inkonsistensinya dalam mempraktikkan ilmu agama yang selama ini degelutinya; kedua, menikah tanpa dicatat oleh Petugas Pencatat Nikah di Kantor Urusan Agama; ketiga, menceraikan dengan alasan sang istri tidak perawan dan tidak memproses perceraian ini melalui sidang Pengadilan Agama; keempat, melanggar sumpah jabatan sebagai pejabat Bupati atau Kepala Daerah; kelima, tindakan melecehkan arti suci makna pernikahan dalam hukum Islam dan merendahkan kaum wanita; dan kelima, nihil keteladanan mulia sebagai pemimpin dan pejabat publik.

Permasalahan pertama adalah inkonsistensinya dalam mempraktikkan ilmu agama yang selama ini digelutinya. Dari biografi Bupati Garut Aceng Fikri, diketahui

5al-Mawardi, al-Ahkām al-Sulțāniyyah, h. 6. 
bahwa selama ini ia menimba ilmu agama secara intensif dan terstruktur secara baik. Setelah tamat dari sebuah Sekolah Dasar Negeri (SDN) Sukamentri Garut, ia melanjutkan ke MTsN Garut, lalu PGAN Garut dan kuliah di sebuah Insitut Agama Islam Ma'arif al-Musaddadiyah. Bahkan, ia juga aktif di pelbagai organisasi di bawah naungan NU, di mana ia pernah menjabat sebagai Sekretaris Gerakan Pemuda Ansor Kabupaten Garut pada tahun 1995-1997. Ia juga pernah menjabat sebagai ketua Garda Bangsa PKB Kabupaten Garut tahun 2001-2002 dan sebagai sekretaris DPC PKB Kabupaten Garut tahun 2002-2006 serta sebagai ketua Masyarakat Pecinta Garut tahun 2002-2006. ${ }^{6}$ Sebagai seorang pelajar dan sarjana Muslim yang masuk dalam kategori tokoh masyarakat dan aktif di berbagai organisasi keislaman, apa yang ia lakukan tentu tidak pantas. Jika saja tidak tersandung kasus wanita, maka nama sang bupati ini akan terus harum. Banyak kalangan memuji kegigihannya hingga mampu menduduki jabatan paling bergengsi di Garut ini.

Permasalahan yang kedua, menikah tanpa dicatat oleh Petugas Pencatat Nikah di Kantor Urusan Agama. Sebagai seorang sarjana Muslim, terlebih sebagai pejabat publik, semestinya hal itu bisa dihindari dan disesuaikan dengan tata aturan yang berlaku di Indonesia. Dalam hal ini, Menteri Agama RI Suryadharma Ali pernah mengemukakan ada upaya mendiskreditkan ajaran Islam dalam kasus ini. Seolaholah nikah sirri adalah bagian dari ajaran Islam, padahal Islam tidak menganjurkan nikah yang berpotensi menimbulkan masalah. Anggapan nikah sirri sebagai anjuran dalam Islam bisa menyesatkan. Nikah sirri memang bisa jadi ada aturannya dalam Hukum Islam dan tidak terlarang, tetapi yang terlarang adalah cara menjalankan perkawinan tersebut. Perlu ditegaskan, bahwa perkawinan adalah pernikahan yang oleh al-Qur'an disebut dengan mïthāqan ghalīzan (ikatan yang sangat kuat dan kokoh). ${ }^{7}$

Menganggap nikah sirri sebagai bagian dari ajaran Islam sungguh salah kaprah. Terdapat sebuah riwayat bahwa pada saat ada seorang sahabat Nabi bernama Abdurrahman ibn Auf menikah dengan seorang wanita Madinah, mantan istri saudara seagamanya. Ketika itu, Abdurrahman berjumpa dengan Nabi SAW di mana saat itu ia sedang bersama istri barunya. Nabi bertanya dan memerintahkan

${ }^{6}$ http://id.wikipedia. diakses, Jumat 21 Juni 2013.

${ }^{7}$ Perhatikan firman Allah sebagai berikut: "Bagaimana kamu akan mengambilnya kembali, Padahal sebagian kamu telah bergaul (bercampur) dengan yang lain sebagai suami-isteri. dan mereka (isteri-isterimu) telah mengambil dari kamu perjanjian yang kuat." (QS. al-Nisā': 21)

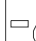

Jurnal Pemikiran Hukum Islam 


\section{Nurul Irfan}

agar Abdurrahman segera melaksanakan walimah atau resepsi, walau hanya sekedar memotong seekor kambing. Perintah Nabi untuk melaksanakan walimah agar tidak menimbulkan fitnah bisa dikontekstualisasikan sebagai perintah untuk mencatatkan pernikahan. Sebab, jika tidak dipublikasikan kepada khalayak, disinyalir akan berakibat negatif bagi status perkawinannya itu. ${ }^{8}$

Dalam riwayat yang lain, dikemukakan bahwa pada suatu malam, saat Nabi SAW sedang beri'tikaf dalam masjid, beliau disusul oleh Sofiyyah istri beliau. Ketika itu ada seseorang yang sedang berada di balik kegelapan malam melihat Nabi yang sedang bersama istrinya itu lari menghindari keduanya. Kemudian Nabi memanggil orang itu untuk memperkenalkan kepadanya bahwa yang sedang bersama beliau ini adalah istri, bukan wanita lain yang tidak halal bersama beliau. Dari riwayat ini pula bisa dimengerti bahwa dalam Islam sangat dianjurkan agar tidak melakukan perbuatan yang bisa mengarah kepada pelbagai fitnah dan kecurigaan umat. ${ }^{9}$

Pernikahan yang hanya dilakukan secara agama tanpa memperhatikan aturan perundang-undangan yang berlaku di sebuah negara jelas sebagai suatu perbuatan yang tidak mulia bahkan dianggap "tercela". Pernikahan bukan hanya perlu memperhatikan aspek hukum Islam atau fikih semata-mata, melainkan harus menjunjung tinggi aturan perundang-undangan sebagai salah satu produk kebijakan pemerintah sebagai uli al-amr.

8Perhatikan Pasal 5 dan 6 Kompilasi Hukum Islam sebagai berikut: Pasal 5 (1) Agar terjamin ketertiban perkawinan bagi masyarakat Islam setiap perkawinan harus dicatat. (2) Pencatatan perkawinan tersebut pada ayat (1), dilakukan oleh Pegawai Pencatat Nikah sebagaimana yang diatur dalam Undang-undang No. 22 Tahun 1946 jo Undang-undang No. 32 Tahun 1954. Pasal 6 (1) Untuk memenuhi ketentuan dalam Pasal 5, setiap perkawinan harus dilangsungkan di hadapan dan di bawah pengawasan Pegawai Pencatat Nikah. (2) Perkawinan yang dilakukan di luar pengawasan Pegawai Pencatat Nikah tidak mempunyai kekuatan Hukum.

${ }^{9}$ Hadis tersebut sebagai berikut:

$$
\begin{aligned}
& \text { عن أنس أن النبي صلى الله عليه وسلم كان مع إحدى نسائه فمر به رجلُ فدعاه فجاء فقال يا فلان } \\
& \text { هذه زوجتي فقال يا رسول الله من كنت أظن به فلم اكن أظن بك فقال رسول الله صلى الله عليه } \\
& \text { وسلم إن الشيطان يجري من ابن آدم مجرى الدم \}رواه النسائى }
\end{aligned}
$$

"Diriwayatkan dari Anas sesungguhnya Nabi SAW pada saat beliau sedang bersama salah seorang istrinya, ketika itu ada seseorang yang berlalu , lalu dipanggil oleh Nabi seraya beliau bersabda, hai Fulan, ini adalah sitriku, maka orang itu berkata wahai Rasulullah seseorang yang engkau duga tidak akan mungkin berburuk sangka kepada engkau, maka beliau bersabda, sungguh setan akan masuk ke dalam tubuh manusia melalui aliran darah," (HR. al-Nasāî). 
Islam sangat menganjurkan agar seseorang melaksanakan pernikahan sekalipun kondisi ekonominya masih pas-pasan, sebab pasti Allah akan memberikan jalan kemudahan bagi seseorang yang telah menikah dengan catatan ia memiliki keyakinan dan sikap tanggung jawab yang tinggi. Dalam khutbah Wukuf Haji Wada', Nabi SAW juga pernah wanti-wanti agar umat Islam bertakwa kepada Allah dengan cara memperlakukan wanita secara baik. Sebab, seorang istri telah dengan rela menyerahkan segenap jiwa dan raganya kepada seorang pria sebagai suaminya, seorang wanita telah mengambil ikrar setia dan kuat dari genggaman tangan pria. Seorang suami dianggap telah memproses "labelisasi" halal dalam bersetubuh dengan seorang wanita dengan dasar kalimat Allah. Di tangan suami, seorang istri ibarat seorang tawanan perang yang harus diperlakukan secara adil dan tidak boleh dizalimi oleh kaum laki-laki. Seorang istri adalah amanat Allah yang dibebankan kepada seorang suami. Jiwa dan raga seorang wanita menjadi halal untuk "dinikmati" oleh seorang pria setelah diucapkannya kata suci dalam al-Qur'an berupa kata "nikah" atau "zawaj" pada saat akad nikah terjadi. Seorang wanita tidak selayaknya diperlakukan sekehendak nafsu laki-laki secara semena-mena dan dianggap sebagai barang yang hanya diukur dengan uang, harta dan kedudukan.

Pernikahan aneh jenis ini bisa dianggap sebagai sebuah bentuk nikah fasid di zaman modern. Nikah singkat tanpa dicatat dan cerai melalu short message service (sms) menurut penulis bisa dikategorikan ke dalam jenis nikah fasid, yaitu nikah yang rusak dan bermasalah. Pernikahan seorang publik figur tanpa didaftarkan ke lembaga perkawinan resmi bisa dianalogikan dengan jual beli pada saat azan Jum'at sedang berkumandang. Jual beli seperti ini dianggap sebagai jual beli yang fasid, sebab yang rusak bukan pada syarat dan rukunnya, melainkan pada sifat atau pelaksanaannya. Demikian halnya pernikahan sang bupati ini yang rusak bukan pada syarat dan rukun-rukunnya, sebab secara fikih boleh jadi memang sudah memenuhi syarat dan rukun. Tetapi aspek ke-fasid-annya terletak pada sifat pernikahan dan cara pelaksanaannya. Sama halnya saat azan Jum'at berkumandang, orang islam wajib segera menuju masjid untuk Salat Jum'at. Tetapi hal sebaliknya terjadi, dalam susana azan sudah terdengar bersahut-sahutan, seseorang justru asyik dengan dunia bisnis, berdagang dan beraktivitas duniawi lainnya padahal ia seorang Muslim. Hal ini akan menyebabkan jual beli yang dilakukan dianggap fasid atau rusak. Demikian halnya seorang bupati Muslim yang faham hukum dan agama tetapi melakukan perkawinan dengan cara sirri, dan tidak dicatatkan dalam lembaga perkawinan kemudian menceraikan istrinya dengan caranya sendiri, sungguh pernikahan seperti ini bisa diangap sebagai nikah fasid. Yaitu pernikahan yang rusak bahkan bisa mem- 


\section{Nurul Irfan}

bawa pelbagai kekacauan dan kerusakan yang lebih besar lagi. Pernikahan siri seperti dalam kasus ini jelas bertentangan dengan sifat nikah itu sendiri, yaitu sebagai sebuah akad yang sangat kuat atau mìthāqan ghalīzan.

Dalam kasus pernikahan Bupati Garut ini, secara agama memang bisa dianggap sah selama telah memenuhi lima rukun berupa adanya calon pengantin pria, calon pengantin wanita, wali dari pihak pengantin wanita, saksi dari kedua belah pihak dan adanya ucapan ijab oleh wali wanita dan qabul oleh pengantin pria. Pernikahan yang telah memenuhi lima rukun tersebut, bukan hanya sah menurut agama, tetapi juga telah dinyatakan sah oleh Pasal 2 ayat (1) UU Perkawinan yang menyebutkan bahwa perkawinan adalah sah apabila dilakukan menurut hukum masing-masing agamanya dan kepercayaannya itu. Dikotomi sah menurut agama, tetapi tidak sah menurut negara ini dipastikan akan terus berlanjut hingga rumusan pasal ini dirubah dengan menyebutkan bahwa jika pernikahan hanya dilakukan secara agama tetapi tidak dicatatkan dalam lembaga perkawinan, maka pernikahannya tidak sah. Sayangnya, hingga kini rumusan pasal ini tidak diutak-atik oleh MK dalam uji materi UU Perkawinan oleh mantan istri siri pejabat penting masa orde baru itu. Bahkan ulama pada saat menyusun Kompilasi Hukum Islam (KHI) Tahun 1990 juga tidak tegas dan terkesan takut untuk menyatakan bahwa jika pernikahan tidak dicatat sesuai dengan peraturan perundang-undangan yang berlaku, maka pernikahan seperti ini dianggap sebagai pernikahan yang tidak sah. Rumusan Pasal 6 ayat (2) KHI hanya menyatakan bahwa pernikahan yang dilakukan di luar pengawasan Pegawai Pencatat Nikah tidak mempunyai kekuatan Hukum.

Kata "tidak memiliki kekuatan hukum" dalam rumusan Pasal 6 ayat (2) KHI ini menunjukkan bahwa ulama pada saat menyusun KHI ini tampak mengalami "kegamangan". Seandainya, para pakar pada saat itu sepakat menyatakan bahwa pernikahan yang dilakukan di luar pengawasan Pegawai Pencatat Nikah tidak sah, maka dikotomi sah menurut agama dan tidak sah menurut negara bisa tertepis dengan sendirinya. Memang dalam hal ini, penulis berasumsi bahwa alih-alih disepakati ketidakabsahan nikah yang tidak terdaftar resmi, justru perdebatan sengit dipastikan pernah terjadi antara dua kubu, kubu yang menganggap sah nikah di bawah tangan dan kubu yang tidak menganggap sah. Di sinilah letak masalah pokok dan akar masalah perdebatan panjang ini.

Kemudian terkait dengan masalah yang ketiga, menceraikan istri dengan alasan sang istri tidak perawan dan tidak memproses perceraian ini melalui sidang Pengadilan Agama, menurut peneliti, ada dua hal ganjil yaitu alasan menceraikan 
yang tidak manusiawi dan pelaksanaan cerai di luar sidang pengadilan. Dalam pelbagai sumber media dikemukakan bahwa alasan menceraikan sang pemimpin atas istrinya, karena Vani Oktara, sang istri tidak perawan lagi karena ekpresinya pada saat di tempat tidur hanya datar-datar saja seolah-olah yang bersangkutan telah biasa menjalankan aktivitas seksual sebelumnya. Hal ini sungguh sangat tidak layak dan sangat menyakitkan perasaan seorang wanita. Bahkan terkait perceraian di luar persidangan, walaupun dalam al-Qur'an dan Hadis tidak disebutkan bahwa perceraian harus dilakukan di depan sidang pengadilan, namun dalam Hukum Islam Indonesia secara tegas disebutkan bahwa perceraian harus dilakukan di depan sidang pengadilan. Dalam Pasal 129 KHI misalnya disebutkan tentang prosedur perceraian sebagai berkut:

Seorang suami yang akan menjatuhkan talak kepada isterinya mengajukan permohonan baik lisan maupun tertulis kepada Pengadilan Agama yang mewilayahi tempat tinggal isteri disertai dengan alasan serta meminta agar diadakan sidang untuk keperluan itu. ${ }^{10}$

Bupati Garut jelas menjatuhkan talaknya di luar sidang pengadilan dan hal ini dipastikan karena sang bupati tidak taat hukum. Jika memang ia sebagai warga negara yang baik, terlebih kapasitasnya sebagai pejabat publik, tentunya ia akan melaksananakan pernikahan di depan petugas pencatat nikah. Tetapi kenyataanya berbeda, pada saat nikah ia hanya melakukannya secara sirri, tanpa dicatat. Maka pada saat cerai pun ia menganggap benar cukup dilakukan secara sepihak dan hanya melalui layanan pesan singkat di handphone atau Blackberry miliknya. Dengan demikian, ada dua pasal yang dilanggar olehnya, yaitu pasal tentang pelaksanaan nikah dan pasal tentang tata cara perceraian. Jika saja ia bertobat dari kesalahan pertama, maka tentu saja ia akan menempuh upaya isbat nikah untuk keperluan perceraian, sebagaimana dimaksudkan oleh Pasal 7 KHI.11

\footnotetext{
${ }^{10}$ M. Nurul Irfan dkk, Status Hukum Anak Luar Nikah di Indonesia, Berdasarkan Putusan MK No. 46/PUU-VIII/2010 (Bandung: Fajar Media, 2013), h. 198.

11Pasal 7 KHI tersebut sebagai berikut: (1) Perkawinan hanya dapat dibuktikan dengan Akta Nikah yang dibuat oleh Pegawai Pencatat Nikah. (2) Dalam hal perkawinan tidak dapat dibuktikan dengan Akta Nikah, dapat diajukan itsbat nikahnya ke Pengadilan Agama. (3) Isbat nikah yang dapat diajukan ke Pengadilan Agama terbatas mengenai hal-hal yang berkenaan dengan: (a) Adanya perkawinan dalam rangka penyelesaian perceraian; (b) Hilangnya Akta Nikah; (c) Adanya keraguan tentang sah atau tidaknya salah satu syarat perkawinan; (d) Adanyan perkawinan yang terjadi sebelum berlakunya Undang-undang No.1 Tahun 1974 dan; (e) Perkawinan yang dilakukan oleh mereka yang tidak mempunyai halangan perkawinan menurut Undang-Undang No.1 Tahun 1974. (4) Yang berhak mengajukan permohonan itsbat nikah ialah suami atau isteri, anak-anak mereka, wali nikah dan pihak yang berkepentingan dengan perkawinan itu.
}

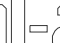

Jurnal Pemikiran Hukum Islam 
Jadi, dalam kasus Bupati Garut ini ada dua kesalahan sekaligus yang ia lakukan, yaitu nikah tidak dicatat dan bercerai tanpa dilakukan di depan sidang pengadilan. Jika dikonfirmasi, dimungkinkan akan ia jawab bahwa menurut hukum Islam (baca: fikih) nikah dan cerai tidak perlu dicatat dan tidak perlu dilakukan di depan pengadilan, dengan berpedoman dengan kitab-kitab klasik tentang masalah ini. Hal senada juga ia kemukakan bahwa ada seorang sahabat Nabi yang bercerai hanya sesaat setelah akad nikah dilakukan. Ia lupa bahwa ia sedang hidup dan berada pada zaman yang berbeda dengan era sahabat Nabi dan di tempat yang tidak sama dengan para sahabat Nabi berdomisisli. Ia berusaha untuk "berdalih" agar segala tindakannya bisa dianggap benar menurut Hukum Islam masa Nabi. Padahal semestinya tidak demikian.

Kemudian terkait dengan masalah yang keempat, melanggar sumpah jabatan sebagai pejabat Bupati atau kepala daerah. Bunyi sumpah jabatan kepala daerah yang dilanggar itu adalah "Demi Allah (Tuhan), saya bersumpah/berjanji akan memenuhi kewajiban saya sebagai Kepala Daerah/Wakil Kepala Daerah dengan sebaik-baiknya dan seadil-adilnya, memegang teguh UUD Negara Republik Indonesia Tahun 1945 dan menjalankan segala undang-undang dan peraturannya dengan selurus-lurusnya serta berbakti kepada masyarakat, nusa dan bangsa."12

Kasus Bupati Garut, jelas terdapat pelanggaran udang-undang. Pada dasarnya, praktek nikah dan talak yang langsungkan di luar prosedur yang telah ditetapkan UU banyak dilakukan oleh anggota masyarakat. Pada umunya, alasan yang mereka kemukakan karena pernikahan adalah sebuah bentuk ibadah yang tidak perlu diatur oleh undang-undang, melainkan cukup didasarkan pada teks Hadis atau pendapat ulama klasik dalam pelbagai kitab fikihnya yang secara umum tidak pernah menentukan bahwa nikah harus dicatat dan talak tidak harus dilakukan di depan sidang pengadilan. Bupati Garut ini, bukan hanya dinilai melanggar UU sebagai produk uli al-amr yang harus ditaati, melainkan ia sebagai salah satu komponen uli al-amr yang seyogianya memberikan contoh dan teladan mulia bagi warga masyarakat, justru memberikan hal yang sebaliknya. Di sinilah letak ketidakbaikan bahkan kezaliman yang semestinya tidak perlu terjadi.

Kemudian terkait masalah yang kelima, nihil keteladanan mulia sebagai pemimpin dan pejabat publik. Sebagai pejabat publik sudah selayaknya jika sang

${ }^{12}$ Detik News, Rabu, Rabu, 05/12/2012 15:12 WIB, dengan judul berita “Jejak Politik Aceng 'Nikah 4 Hari' Inilah UU dan Sumpah Jabatan yang Dilanggar Aceng". 
bupati memberikan teladan dan contoh perilaku mulia bagi warganya. Sebab hakikat seorang pemimpin adalah pelayan bagi masyarakat luas.

\section{Kewajiban Pokok Kepala Daerah}

Pelbagai berita baik di surat kabar, televisi maupun media online, dapat diketahui bahwa perilaku Aceng Fikri sebagai Bupati Garut ini mendapat reaksi keras dari masyarakat hingga menghadapi krisis kepercayaan publik secara meluas. Oleh sebab itu, berdasarkan Pasal 32 ayat (1) UU No. 32 Tahun 2004 tentang Pemerintah Daerah, DPRD Kabupaten Garut menggunakan hak angketnya untuk menanggapi kasus ini untuk kemudian diproses lebih lanjut hingga Presiden RI memberhentikannya. Ketentuan Pasal 32 ayat (1), (2) dan (3) UU No. 32 Tahun 2004 tersebut adalah sebagai berikut:

(1) Dalam hal kepala daerah dan/atau wakil kepala daerah menghadapi krisis kepercayaan publik yang meluas karena dugaan melakukan tindak pidana dan melibatkan tanggung jawabnya, DPRD menggunakan hak angket untuk menanggapinya.

(2) Penggunaan hak angket sebagaimana dimaksud pada ayat (1) dilaksanakan setelah mendapatkan persetujuan Rapat Paripurna DPRD yang dihadiri oleh sekurang-kurangnya 3/4 (tiga perempat) dari jumlah anggota DPRD dan putusan diambil dengan persetujuan sekurang-kurangnya 2/3 (dua pertiga) dari jumlah anggota DPRD yang hadir untuk melakukan penyelidikan terhadap kepala daerah dan/atau wakil kepala daerah.

(3) Dalam hal ditemukan bukti melakukan tindak pidana sebagaimana dimaksud pada ayat (1), DPRD menyerahkan proses penyelesaiannya kepada aparat penegak hukum sesuai dengan peraturan perundang-undangan. ${ }^{13}$

Adapun terkait kewajiban-kewajiban pokok bagi seorang kepala daerah dan wakil kepala daerah bisa dilihat ketentuan Pasal 27 UU No. 32 Tahun 2004 tentang Pemerintahan Daerah sebagai berikut:

(1) Dalam melaksanakan tugas dan wewenang sebagaimana dimaksud dalam Pasal 25 dan Pasal 26, kepala daerah dan wakil kepala daerah mempunyai kewajiban: a) memegang teguh dan mengamalkan Pancasila, melaksanakan Undang-Undang Dasar Negara Republik Indonesia Tahun 1945 serta mempertahankan dan memelihara keutuhan Negara Kesatuan Republik

\footnotetext{
13Undang-Undang Republik Indonesia No. 32 dan 33 Tahun 2004 (Bandung: Citra Umbara, 2013), h. 28.
} 
Indonesia; b) meningkatkan kesejahteraan rakyat; c) memelihara ketenteraman dan ketertiban masyarakat; d) melaksanakan kehidupan demokrasi; e) menaati dan menegakkan seluruh peraturan perundang-undangan; f) menjaga etika dan norma dalam penyelenggaraan pemerintahan daerah;

g) memajukan dan mengembangkan daya saing daerah; h) melaksanakan prinsip tata pemerintahan yang bersih dan baik; i) Melaksanakan dan mempertanggungjawabkan pengelolaan keuangan daerah; j) menjalin hubungan kerja dengan seluruh instansi vertikal di daerah dan semua perangkat daerah; k) menyampaikan rencana strategis penyelenggaraan pemerintahan daerah di hadapan Rapat Paripurna DPRD.

(2) Selain mempunyai kewajiban sebagaimana dimaksud pada ayat (1), kepala daerah mempunyai kewajiban juga untuk memberikan laporan penyelenggaraan pemerintahan daerah kepada pemerintah, dan memberikan laporan keterangan pertanggungjawaban kepada DPRD, serta menginformasikan laporan penyelenggaraan pemerintahan daerah kepada masyarakat.

(3) Laporan penyelenggaraan pemerintahan daerah kepada pemerintah sebagaimana dimaksud pada ayat (2) disampaikan kepada Presiden melalui Menteri Dalam Negeri untuk Gubernur, dan kepada Menteri Dalam Negeri melalui Gubernur untuk Bupati/Walikota 1 (satu) kali dalam 1 (satu) tahun.

(4) Laporan sebagaimana dimaksud pada ayat (3) digunakan Pemerintah sebagai dasar melakukan evaluasi penyelenggaraan pemerintahan daerah dan sebagai bahan pembinaan lebih lanjut sesuai dengan peraturan perundang-undangan.

(5) Pelaksanaan ketentuan sebagaimana dimaksud pada ayat (1), ayat (2), ayat (3), dan ayat (4) diatur dalam Peraturan Pemerintah.

Di antara kewajiban kepala daerah yang terkait dengan pelanggaran UU dan norma pemerintahan, secara tegas disebutkan pada Pasal 27 ayat (1) huruf e dan f, yaitu seorang kepala daerah dan wakil kepala daerah wajib e. menaati dan menegakkan seluruh peraturan perundang-undangan; f. menjaga etika dan norma dalam penyelenggaraan pemerintahan daerah. Rumusan pasal ini sejalan dengan pasal tentang larangan melanggar sumpah jabatan yang di antara isinya adalah bahwa kepala daerah dan wakil kepala daerah akan taat terhadap undang-undang.

\section{Korelasi Mekanisme Pemberhentian Bupati Garut dengan Pemikiran al-Mawardi}

Terkait mekanisme pemberhentian, kewajiban bagi kepala daerah dan pemberhentian serta alasan seorang kepala daerah bisa diberhentikan, dapat dicermati 
kembali rumusan Pasal 27, 28 dan 29 UU No. 32 Tahun 2004 tentang Pemerintah Daerah di atas. Jika dibandingkan secara cermat, antara rumusan ketiga pasal terkait kewajiban, larangan dan pemberhentian seorang kepala daerah dengan pemikiran al-Mawardi mengenai pengangkatan seorang pemimpin dan alasan-alasan pokok seorang pemimpin bisa diberhentikan, ternyata terdapat korelasi pada bagian tertentu, yakni pada masalah pelanggaran terhadap larangan-larangan sebagaimana akan penulis kemukakan pada bagian berikutnya.

Menurut Pasal 27, 28 dan 29 UU No. 32 Tahun 2004 tentang Pemerintah Daerah, sebab utama seorang kepala daerah bisa diberhentikan karena ia terbukti tidak mampu menjalankan kewajibannya dan nyata-nyata telah melanggar janji dan sumpah jabatan. Kemudian menurut al-Mawardi, terdapat dua sebab pokok yang berakibat seorang kepala negara bisa diberhentikan, yaitu: pertama, karena ia kehilangan sifat adil dan; kedua, ia mengalami cacat fisik. Yang dimaksud dengan kehilangan sifat adil adalah karena yang bersangkutan memiliki sifat fasiq dengan beberapa indikasi seperti cenderung mengikuti hawa nafsu, melakukan pelanggaran atas larangan-larangan, melaksanakan perbuatan mungkar, dan ia telah diperbudak oleh hawa nafsunya.14 Menurutnya ada sebab lain yang bersifat fisik berupa: pertama, kehilangan fungsi akal dan alat penglihatan; kedua kehilangan organ tubuh secara fisik, dan; ketiga kehilangan kemampuan menggunakan organ tubuh yang masih utuh secara fisik. Dengan demikian, terdapat benang merah yang bisa ditarik dari pemikiran al-Mawardi yaitu sikap seorang pemimpin yang tidak adil karena telah memperturutkan hawa nafsunya dan cenderung mengikuti selera rendahnya. Melakukan pelanggaran-pelanggaran terhadap larangan-larangan, melaksanakan perbuatan mungkar, merupakan sebuah alasan seorang kepala daerah bisa diberhentikian. ${ }^{15}$

Bupati Garut, dalam kasus di atas telah berlaku tidak adil. Hanya saja indikasi ketidakadilannya berbeda dengan apa yang dikemukakan imam al-Mawardi. Kalau al-Mawardi menjelaskan bahwa seorang pemimpin telah dinilai tidak adil jika ia telah memiliki kebiasaan fasiq dengan beberapa indikasi seperti melakukan pelanggaran terhadap larangan (al-maḥūūāt), terbiasa melakukan kemungkaran dan cenderung mengikuti hawa nafsu. ${ }^{16}$ Sedangkan, menurut penulis letak

\footnotetext{
${ }^{14}$ al-Mawardi, al-Ahkām al-Sulțāniyyah, h. 17.

15 Ibid.

16 Ibid.

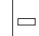

Jurnal Pemikiran Hukum Islam
} 


\section{Nurul Irfan}

ketidakadilan Bupati Garut Aceng Fikri berupa telah melanggar sumpah jabatan yang isi pokoknya ia sebagai kepala daerah akan memenuhi kewajiban dengan sebaik-baiknya dan seadil-adilnya, memegang teguh UUD Negara Republik Indonesia Tahun 1945 dan menjalankan segala Undang-Undang dan peraturannya dengan selurus-lurusnya."17 Ia telah berjanji akan berlaku adil, tetapi pada perjalanan kepemimpinannnya melakukan hal-hal sebaliknya seperti tidak taat terhadap UU. Padahal, dalam Pasal 27 angka (1) huruf e disebutkan bahwa kepala daerah mempunyai kewajiban utuk menaati dan menegakkan seluruh peraturan perundang-undangan. Di antara peraturan perundang-undangan ini adalah UU No. 1 Tahun 1974 yang dalam Pasal 2 ayat (2) menegaskan bahwa tiap-tiap perkawinan dicatat sesuai dengan peraturan perundang-undangan. Undang-undang lain yang tidak ia taati adalah UU No. 32 Tahun 2004 tentang Pemerintah Daerah yang pada Pasal 27, 28 dan 29 secara tegas telah mengatur berbagai hal terkait kewajiban kepala daerah, larangan bagi kepala daerah dan pemberhentian kepala daerah sebagaimana telah diuraikan di atas.

Indikasi ketidakadilan kepala daerah menurut al-Mawardi yang cukup menarik untuk dicermati lebih lanjut adalah sikap melanggar larangan atau yang disebut oleh al-Mawardi sebagai al-mahzūūāt. Kata al-maḩūūrāt ini tidak digabungkan dengan sebutan al-maḥūūāt al-shar'ìyah atau larangan-larangan syara' sebagaimana pada saat al-Mawardi mendefinisikan tindak pidana dalam kitab yang sama dengan kalimat maḩ̣ūrātun shar'iyyatun zajara Allāhu ta'āla 'anhā bi jiddin aw ta'zïr (larangan-larangan syara' yang diancam oleh Allah dengan hukuman had dan takzir). ${ }^{18}$ Hal ini menunjukkan bahwa larangan di sini bukan yang bersifat syara', melainkan larangan yang ditetapkan oleh otoritas tertentu dalam sebuah Negara. Oleh sebab itu, larangan bagi kepala daerah dan wakil kepala daerah yang dijelaskan pada Pasal 28 huruf a sampai dengan g UU No. 32 Tahun 2004 tentang Pemerintah Daerah jelas-jelas bisa dikategorikan ke dalam cakupan makna al-maḩūūrāt yang dikemukakan oleh al-Mawardi. Dengan demikian, terdapat korelasi antara konsep pemikiran al-Mawardi tentang alasan pemberhentian seorang pemimpin atau kepala daerah dengan mekanisme pemberhentian kepala daerah sebagaimana diatur dalam UU No. 32 Tahun 2004 tentang Pemerintah Daerah.

${ }^{17}$ Detik News, "Jejak Politik Aceng....”

18al-Mawardi, al-Ahkām al-Sulțāniyyah, h. 217.

106 Volume 24, Nomor 1, April 2014

Jurnal Pemikiran Hukum Islam 
Dari uraian di atas dapat penulis simpulkan bahwa Bupati Garut Aceng Fikri yang diberhentikan karena dianggap telah melanggar sumpah jabatan sebagaimana disebutkan dalam Pasal 29 angka (2) huruf d menurut al-Mawardi dapat dianggap sebagai kepala daerah yang tidak mampu berbuat adil dan telah menjadi seorang yang dapat dinilai fasiq karena ia melakukan pelanggaran terhadap larangan (al-maḥūūrāt) dan cenderung mengikuti hawa nafsunya. Untuk menguatkan bahwa ia telah mengikuti hawa nafsunya, dalam pelbagai berita, Bupati Garut memiliki beberapa teman dekat wanita dan tersandung oleh godaan menggiurkan di antara tiga "ta" yaitu tahta, harta dan wanita.

\section{Pemberhentian Bupati Garut Perspektif Fikih Siyāsah al-Mawardi}

Bupati Garut Aceng Fikri diberhentikan atas dasar UU No. 32 Tahun 2004 tentang Pemerintah Daerah. Pasal pokok yang dijadikan alasan ia harus diberhentikan adalah karena setelah dilakukan investigasi oleh tim DPRD Garut ia terbukti melakukan pelanggaran sumpah jabatan. Kemudian pelbagai langkah dan prosedur pemberhentiannya juga telah ditempuh sesuai dengan peraturan-perundang-undangan yang berlaku, dalam hal ini adalah Pasal 29 angka (4) huruf a sampai e. UU No. 32 Tahun 2004 tentang Pemerintah Daerah yang menyatakan bahwa pemberhentian kepala daerah dan/atau wakil kepala daerah sebagaimana dimaksud pada ayat (2) huruf d dan huruf e dilaksanakan dengan ketentuan: a) Pemberhentian kepala daerah dan wakil kepala daerah diusulkan kepada presiden berdasarkan putusan Mahkamah Agung atas pendapat DPRD bahwa kepala daerah dan/atau wakil kepala daerah dinyatakan melanggar sumpah/janji jabatan dan/atau tidak melaksanakan kewajiban kepala daerah dan wakil kepala daerah; b) Pendapat DPRD sebagaimana dimaksud pada huruf a diputuskan melalui Rapat Paripurna DPRD yang dihadiri oleh sekurangkurangnya 3/4 (tiga perempat) dari jumlah anggota DPRD dan putusan diambil dengan persetujuan sekurang-kurangnya 2/3 (dua pertiga) dari jumlah anggota DPRD yang hadir; c) Mahkamah Agung wajib memeriksa, mengadili, dan memutus pendapat DPRD tersebut paling lambat 30 (tiga puluh) hari setelah permintaan DPRD itu diterima Mahkamah Agung dan putusannya bersifat final; d) Apabila Mahkamah Agung memutuskan bahwa kepala daerah dan/atau wakil kepala daerah terbukti melanggar sumpah/ janji jabatan dan/atau tidak melaksanakan kewajiban, DPRD menyelenggarakan Rapat Paripurna DPRD yang dihadiri oleh sekurang-kurangnya 3/4 (tiga perempat) dari jumlah anggota DPRD dan putusan diambil dengan persetujuan sekurang-kurangnya 2/3 (dua pertiga) dari jumlah anggota DPRD yang hadir untuk 


\section{Nurul Irfan}

memutuskan usul pemberhentian kepala daerah dan/atau wakil kepala daerah kepada Presiden; e) Presiden wajib memroses usul pemberhentian kepala daerah dan/atau wakil kepala daerah tersebut paling lambat 30 (tiga puluh) hari sejak DPRD menyampaikan usul tersebut.

Langkah dan prosedur pemberhentian Bupati Garut Aceng Fikri sebagaimana dikemukakan secara sangat rinci dalam rumusan Pasal 29 angka 4 huruf a sampai dengan huruf e UU No. 32 Tahun 2004 tentang Pemerintah Daerah tersebut tentu saja tidak pernah dikemukakan oleh imam al-Mawardi. Dalam bukunya al-Ahkām al-Sulțāniyyah, al-Mawardi memaparkan bahwa terdapat dua sebab pokok seorang pemimpin, kepala negara atau kepala daerah bisa diberhentikan, yaitu pertama karena ia kehilangan sifat adil dan kedua ia mengalami cacat fisik. Maksud kehilangan sifat adil adalah karena yang bersangkutan memiliki sifat fasiq dengan beberapa indikasi seperti melakukan pelanggaran-pelanggaran terhadap larangan, melaksanakan perbuatan mungkar, dan ia telah diperbudak oleh hawa nafsunya. ${ }^{19}$

Dengan demikian, secara prosedur apa yang dijelaskan al-Mawardi masih bersifat sederhana, tidak bersifat rinci dan prosedural sebagaimana dirumuskan dalam pasal-pasal di atas. Namun, dari sisi struktrur pemerintah, di zaman alMawardi hidup ternyata telah dikenal sebuah lembaga pengontrol pemerintah yaitu parlemen atau ahl al-halli wa 7-'aqdi. Terkait pemberhantian kepala daerah atau pemimpin ini, al-Mawardi berkata, kalau seorang imam atau kepala daerah telah secara sah menduduki jabatan dan telah didukung oleh masyarakat luas seperti yang kami uraikan pada bagian terdahulu, maka seorang kepala daerah itu wajib ditaati dan warga masyarakat harus tunduk dengan kebijakan-kebijakannya, dengan catatan, ia tidak melakukan pelbagai penyimpangan. Tetapi jika seorang pemimpin telah melakukan penyimpangan, melakukan berbagai pelanggaran atas pelbagai larangan yang telah ditetapkan, maka ia harus dilengserkan. Menurut alMawardi, terdapat dua sebab pokok seorang kepala negara atau kepala daerah bisa diberhentikan, yaitu pertama karena ia kehilangan sifat adil dan kedua ia mengalami cacat fisik. Yang dimaksud dengan kehilangan sifat adil adalah karena yang bersangkutan memiliki sifat fasiq dengan beberapa indikasi seperti cenderung mengikuti hawa nafsu, melakukan pelanggaran terhadap pelbagai larangan yang telah ditetapkan, melaksanakan perbuatan mungkar, dan ia telah diperbudak oleh hawa nafsunya. ${ }^{20}$ Permasalahan lainnya adalah bagaimana kalau

${ }^{19} \mathrm{Ibid}$, h. 17.

${ }^{20}$ Ibid.

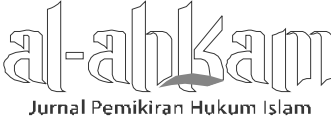


ia telah berhenti dari sikap tidak adilnya dan telah kembali memiliki sifat adil? Apakah otomatis tetap jadi pemimpin atau tidak? Menurut al-Mawardi tidak bisa secara otomatis, melainkan harus ada proses pemilihan dari awal dan dibai'at atau dilantik lagi.

Jika diperbandingkan antara rumusan Pasal 29 angka (4) huruf a sampai e. UU No. 32 Tahun 2004 tentang Pemerintah Daerah dengan pernyataan al-Mawardi, maka terdapat korelasi pada bagian pelanggaran terhadap aturan-aturan yang telah ditetapkan dan dilanggar oleh kepala daerah tersebut. Pada Pasal 29 angka (4) huruf d secara tegas disebutkan bahwa Kepala daerah dan/atau wakil kepala daerah sebagaimana dimaksud pada ayat (1) huruf c diberhentikan karena dinyatakan melanggar sumpah/janji jabatan kepala daerah dan/atau wakil kepala daerah. Inilah aturan yang dilanggar oleh Bupati Garut Aceng Fikri. Sedangkan alMawardi mengemukakan bahwa seorang pemimpin bisa diberhentikan apabila ia tidak bisa berlaku adil. Indikasi seorang tidak bisa berbuat adil adalah jika ia melanggar pelbagai larangan atau al-mahzūurāt. Larangan yang dimaksudkan oleh al-Mawardi jelas bukan sebagai larangan-larangan agama, melainkan laranganlarangan yang telah ditetapkan oleh otoritas berwenang. Untuk konteks Indonesia, antara lain adalah Pasal 29 angka (4) huruf d UU No. 32 Tahun 2004 tentang Pemerintah Daerah, yaitu ia diberhentikan karena dinyatakan melanggar sumpah/ janji jabatan.

Jika pada saat dilantik Bupati Garut telah menyatakan bahwa sebagai kepala daerah ia berjanji dan bersumpah akan memenuhi kewajiban sebagai Kepala Daerah/Wakil Kepala Daerah dengan sebaik-baiknya dan seadil-adilnya, memegang teguh UUD Negara Republik Indonesia Tahun 1945 dan menjalankan segala Undang-Undang dan peraturannya dengan selurus-lurusnya, maka janji itu telah ia langgar sendiri dengan melakukan perkawinan siri atau perkawinan yang tidak dicatat pada lembaga yang berwenang yaitu Kantor Urusan Agama (KUA) setempat. Perkawinan yang tidak dicatat jelas melanggar Pasal 2 ayat (2) UU No. 1 Tahun 1974 tentang Perkawinan.

\section{Kesimpulan}

Dari uraian penelitian di atas dapat penulis simpulkan sebagai berikut: pertama, proses dan mekanisme pemberhentian Bupati Garut Aceng Fikri menurut pemikiran fikih siyāsah al-Mawardi bisa dibenarkan, sebab menurutnya seorang pemimpin atau kepala daerah dapat diberhentikan dari jabatannya jika ia 


\section{Nurul Irfan}

telah dinyatakan tidak adil dalam menjalankan tugasnya sebagai kepala daerah. Ketidakadilannya terletak pada indikasi adanya pelanggaran-pelanggaran terhadap larangan-larangan yang telah ditetapkan oleh otoritas yang berwenang. Dalam hal ini Pasal 28 huruf f UU No. 32 Tahun 2004 tentang Pemerintah Daerah yang menyatakan bahwa kepala daerah dan wakil kepala daerah dilarang menyalahgunakan wewenang dan melanggar sumpah/janji jabatannya. Adapun prosedur pemberhentiannya yang telah ditetapkan secara rinci dan sangat prosedural sebagaimana diuraikan pada Pasal 29 angka (4) huruf a sampai e UU No. 32 Tahun 2004 tentang Pemerintah Daerah tidak ditemukan secara rinci dalam buku alMawardi al-Aḥkām al-Sulțāniyyah karena buku ini merupakan karya klasik dan bukan sebagai sebuah undang-undang melainkan sebuah hasil pemikiran politik al-Mawardi sebagai pemikir dan ahli politik Islam secara pribadi.

Kedua, konsep pemikiran fikih siyāsah al-Mawardi sekecil apapun bisa diimplementasikan dalam kehidupan berpolitik di Indonesia. Khususnya pemikirannya terkait alasan seorang kepala Negara atau kepala daerah bisa diangkat atau diberhentikan jika yang bersangkutan telah memenuhi syarat atau ia telah berlaku tidak adil dan tidak bisa menjalankan tugasnya sebagaimana diatur dalam UU No. 32 Tahun 2004 tentang Pemerintah Daerah. Di antara indikasi ketidakadilan seorang kepala negara atau kepala daerah adalah jika ia telah melakukan pelanggaran terhadap larangan-larangan yang telah ditetapkan sesuai aturan perundangundangan. Larangan dimaksud antara lain disebutkan dalam Pasal 28 huruf a sampai dengan huruf g UU No. 32 Tahun 2004 tentang Pemerintah Daerah.

Ketiga, terdapat relevansi yang sangat erat antara pemikiran Fikih Siyāsah alMawardi dengan mekanisme pemberhentian seorang kepala daerah di Indonesia sebagaimana diatur dalam UU No. 32 Tahun 2004 tentang Pemerintah Daerah. Relevansi antara keduanya antara lain terletak pada masalah alasan seorang kepala negara atau kepala daerah bisa diberhentikan, yaitu sebab ia telah melanggar sumpah jabatan. Isi pokok sumpah jabatan adalah bahwa seorang kepala negara atau kepala pemerintah bersumpah/berjanji akan memenuhi kewajibannya sebagai kepala daerah/wakil kepala daerah dengan sebaik-baiknya dan seadil-adilnya, memegang teguh UUD Negara Republik Indonesia Tahun 1945 dan menjalankan segala undang-undang dan peraturannya dengan selurus-lurusnya. Jika sumpah ini dilanggar, maka berarti kepala daerah atau wakil kepala daerah tersebut jelas terbukti tidak bisa berlaku adil, sehingga ia dapat diberhentikan. [a] 


\section{DAFTAR PUSTAKA}

Amiruddin dan Zainal Asikin, Pengantar Metode Penelitian Hukum, Jakarta: Rajawali Pers, 2004.

al-'Asqalanī, Ibn Hajar, Bulūgh al-Marām, Semarang: Toha Putra, t.th.

Awdah, Abdul Qādir, al-Tashrī' al-Jinā'ī al-Islāmī, Beirut: Mu'assasah ar-Risālah, t.th.

Habibie, Bacharuddin Jusuf, Habibie dan Ainun, Jakarta: THC Mandiri: 2010.

Hidayat, Komaruddin , Dilema Intelektual dalam Kompas, Jumat 14 Juni 2013.

al-Hijāwī, Mūsa, al-Iqnā' fi Halli al-Fāẓi Abī Syujā', Seri al-Maktabah al-Shāmilah.

Irfan, M Nurul, Nasab dan Status Anak dalam Hukum Islam, Jakarta: Amzah, 2012.

Irfan, M Nurul, “Nikah Siri”, dalam Republika, Rabu 5 Desember 2012.

Irfan, M Nurul, Status Hukum Anak Luar Nikah di Indonesia, Berdasarkan Putusan MKNo. 46/PUU-VIII/2010, Bandung: Fajar Media, 2013.

al-Jauzī, Ibn, al-Qawānīn al-Fiqhiyyah, Seri al-Maktabah al-Shāmilah.

Kementerian Pendidikan Nasional, Kamus Besar Bahasa Indonesia, Jakarta: Balai Pustaka, 2003.

Khallāf, Abdul Wahhāb, Ilmu Ușūl al-Fiqh, t.t.p.: Dar al-'Ilmi, 1978.

al-Kasānī, Abū Bakar ibn Mas'ūd ibn Aḥmad, Badāi' al-Ṣanāi', Seri al-Maktabah alShāmilah.

al-Khāțib, Sharbin̄̄, Hāshiyah al-Bujairimi 'ala 'l-Khāțib, Seri al-Maktabah alShāmilah.

al-Mawsū'ah al-Fiqhiyyah, Haqīqah Nikāh al-Sirri, Seri al-Maktabah al-Shāmilah

al-Mawardī, al-Ahkām al-Sulțāniyyah, Beirut: Dar al-Fikr, t.th.

al-Nawāwī, Abū Zakariya Yahya ibn Sharaf, Ṣahīh Muslim, Sharḥ al-Nawāwī, Riyāḍ: Bayt al-Afkār ad-Dawliyyah, t.th.

Pramodhawardani, Jaleswari, "Pejabat dan Tubuh Perempuan", Kompas, Jumat 7 Desember 2012.

Rushd, Ibn, Bidāyat al-Mujtahid wa Nihāyat al-Muqtașid, Semarang: Toha Putera, t.th.

al-Shāṭibī, Abu Isḥāq Ibrāhīm Ibn Mūsā al-Lahmī, al-Muwāfaqāt fì Ușūl al-Aḥkām, Mesir: Dar al-Fikr, 1341.

Soekanto, Soerjono, Pengantar Penelitian Hukum, Jakarta: UI-Press, 1986.

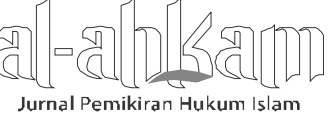


M. Nurul Irfan

Syarif, Mujar Ibnu dan Hamami Zada, Fikih Siyasah, Doktrin dan Pemikiran Politik Islam, Jakarta: Erlangga, 2008.

Tim Penyusun, al-Mu'jam al-Awsāț, Seri al-Maktabah al-Shāmilah.

Undang-Undang Republik Indonesia No. 32 Tahun 2004 tentang Pemerintahan Daerah.

Van Hoeve, Ensiklopedi Hukum Islam, Jakarta: Ichtiar Baru, 1997.

Zahrah, Muhammad Abū, Ușūl al-Fiqh, Beirut: Dar al-Fikr, t.th.

al-Zuhaylī, Wahbah, al-Fiqh al-Islāmī wa Adillatuhu, Lubna: Dar al-Fikr, 1997.

Internet:

Detik News, Rabu, “Jejak Politik Aceng 'Nikah 4 Hari' Inilah UU dan Sumpah Jabatan yang Dilanggar Aceng” diakses Rabu, 5 Desember 2012. 